\title{
Perilaku Menolong Relawan Spontan Bencana Alam
}

\author{
Masitha Hanum Utomo', Wenty Marina Minza ${ }^{2}$ \\ 1,2 Fakultas Psikologi Universitas Gadjah Mada
}

\begin{abstract}
The vulnerable conditions of Indonesia, especially Yogyakarta, to natural disasters led a lot of volunteers who want to help the survivor. Many of volunteers joined the social community or formal organization, but many of them do not belong to any social community or organization and does not have the ability to handle the condition of natural disaster still help the victims. These individuals referred as spontaneous volunteers. The aim of this study is to determine the helping behavior conducted by spontaneous volunteers. The approach used in this study is qualitative specifically phenomenology. Data was collected by a semistructured in-depth interview. Informants of this study consisted of three individuals, two of them was volunteered when the eruption of Mount Merapi occurred in 2010, and the other one was volunteered in Banjarnegara's landslide in 2014. Result showed that there are changes of helping behavior from spontaneous to formal planned form of helping. There are also several factors that encourage or inhibit their helping behavior.
\end{abstract}

Keywords: helping behavior, spontaneous volunteer, natural disaster

Abstrak. Kondisi bencana alam yang rawan terjadi di Indonesia, khususnya di Yogyakarta dan sekitarnya memunculkan banyak relawan yang ingin terjun ke lokasi dan menolong para korban bencana alam. Sebagian relawan, tergabung dalam organisasi maupun komunitas sosial, namun ada yang tidak tergabung yang disebut sebagai relawan spontan. Penelitian ini bertujuan untuk mengetahui bagaimana perilaku menolong yang dilakukan oleh relawan spontan bencana alam. Pendekatan yang digunakan dalam penelitian ini adalah kualitatif fenomenologi. Metode pengambilan data menggunakan wawancara mendalam semi terstruktur. Informan penelitian terdiri dari tiga orang, dua di antaranya pernah terjun ke lokasi erupsi Gunung Merapi pada tahun 2010 dan satu orang terjun ke lokasi longsor Banjarnegara pada tahun 2014. Hasil analisis data ditemukan bahwa terjadi perubahan bentuk perilaku menolong pada ketiga informan yang awalnya spontan menjadi perilaku menolong terencana. Ditemukan pula terdapat beberapa faktor yang mendorong maupun menghambat munculnya perilaku menolong pada ketiga informan.

Kata kunci: bencana alam, perilaku menolong, relawan spontan

${ }^{1}$ Korespondensi mengenai isi artikel ini dapat dilakukan melalui: masitha.hanum.u@mail.ugm.ac.id

${ }^{2}$ Atau melalui wminza@ugm.ac.id 
Indonesia dikenal sebagai salah satu negara yang rawan terkena bencana alam. Terletak di antara pertemua tiga lempeng tektonik yang bertumbukan yaitu Lempeng Indo-Australia, Lempeng Eurasia, dan Lempeng Pasifik membuatnya rawan terkena berbagai macam bencana alam. Ketika salah satu dari lempeng tersebut bergerak, maka akan terjadi gempa bumi, letusan gunung berapi, dan tsunami di Indonesia (CFE-DMHA, 2015). Selain karena ketiga lempeng tektonik tersebut, Indonesia juga terletak di jalur gempa bumi dan gunung berapi yang dinilai paling dahsyat menurut United States Geological Surveys (USGS). Jalur yang dikenal dengan nama Pacific Ring of Fire ini terbentang dari belahan bumi bagian barat tepatnya di Chile, kemudian melewati Jepang dan Asia Tenggara (Israel, 2010). Indonesia juga memiliki kurang lebih 130 gunung berapi aktif yang tersebar di berbagai pulau (Saul, 2014). Salah satu gunung berapi paling aktif adalah Gunung Merapi yang terletak di Daerah Istimewa Yogyakarta.

Salah satu kota di Indonesia yang berpotensi tinggi terkena bencana alam adalah Daerah Istimewa Yogyakarta. Provinsi yang diberikan keistimewaan oleh Pemerintah Republik Indonesia ini dinilai berpotensi tinggi terkena bencana alam karena wilayah selatannya didominasi oleh pesisir pantai dan pada wilayah bagian utara berdiri tegak salah satu gunung berapi paling aktif yaitu Gunung Merapi. Menurut Kepala Badan Penanggulangan Bencana Daerah (BPBD) DIY, Gatot Saptadi, 68\% wilayah Daerah Istimewa Yogyakarta merupakan daerah rawan bencana. Pernyataan tersebut didukung oleh Deputi Bidang Logistik dan Peralatan Badan Nasional Penanggulangan Bencana (BNPB), Bambang Sulistio yang mengatakan wilayah DIY bagian selatan berpotensi terkena bencana tsunami dan gempa bumi dahsyat (Veriawan, 2014).

Dalam kurun waktu lima belas tahun terakhir, terdapat beberapa bencana alam dahsyat yang terjadi di Indonesia dan dua diantaranya terjadi di Yogyakarta. Sabtu, 27 Mei 2006 tepatnya pada pukul 5.53 WIB bagian selatan tanah Ngayogyakarto Hadiningrat diguncang gempa dahsyat berkekuatan 6.3 skala richter. Gempa tersebut meluluhlantahkan wilayah Kabupaten Bantul dan menelan sedikitnya 5.162 korban jiwa. Tercatat sekitar 33.616 rumah penduduk pun rusak parah akibat gempa yang berlangsung selama 57 detik tersebut (Martono, 2013). Empat tahun kemudian, Yogyakarta kembali berduka. Gunung Merapi yang menjadi simbol kegagahan Daerah Istimewa Yogyakarta menyemburkan lahar dan awan panas tepatnya pada tanggal 26 Oktober 2010. Erupsi tersebut merupakan yang terbesar dalam kurun waktu 100 tahun terakhir dan menelan sekitar 200 korban jiwa (Malau \& Waskita, 2013).

Tak dapat dipungkiri, terjadinya bencana alam menimbulkan banyak sekali dampak negatif bagi kehidupan masyarakat, di antaranya adalah timbul korban jiwa yang tidak sedikit, hilangnya harta benda, kerusakan lingkungan, dan terganggunya fungsi psikologis para korban bencana alam. Penanganan terhadap dampak negatif yang timbul haruslah dilakukan sesegera mungkin setelah bencana alam terjadi. Semakin cepat proses penanganan dilakukan maka semakin banyak pula dampak negatif yang dapat dikurangi serta dapat mempercepat pula proses pemulihan fungsi psikologis pada korban bencana alam.

Menangani dampak negatif yang timbul setelah bencana alam terjadi bukan merupakan sebuah hal yang mudah. Banyak hal-hal yang harus dikuasai, diperhatikan, 
dan tentunya hal ini tidak dapat dilakukan sendirian. Dibutuhkan kerjasama dan keterlibatan banyak individu dalam melakukan proses tersebut. Di Indonesia, gotong royong merupakan salah satu bentuk kerja sama yang sering dilakukan untuk menangani bencana alam. Gotong royong merupakan suatu bentuk kerja sama yang pelaksanaannya melalui pengerahan tenaga untuk mencapai suatu tujuan tertentu (DEPDIKBUD, 1982). Sistem gotong royong sendiri sudah berkembang di Indonesia sejak zaman kejayaan Kerajaan Hindu di pulau Jawa. Masyarakat desa sekitar pulau Jawa menyebut gotong royong dengan istilah sambatan atau sambat sinambat. Sambatan berasal dari kata sambat yang berarti "mengeluh" kemudian dihubungkan dengan kata nyambat yang diartikan dengan "minta tolong". Lalu seterusnya gotong royong selalu dikaitkan dengan kegiatan tolong menolong. Menurut penelitian yang telah dilakukan Departemen Pendidikan dan Kebudayaan mengenai sistem gotong royong dalam masyarakat pedesaan di Yogyakarta tahun 1982, pelaksanaan kegiatan gotong royong ini hanya melibatkan beberapa individu terdekat yang berada dalam satu lingkungan, misalnya seperti tetangga rumah (DEPDIKBUD, 1982).

Pada perkembangannya, proses tolong menolong tidak hanya diwujudkan dalam bentuk gotong royong. Bahkan tolong menolong dalam konteks penanganan bencana alam seringkali melibatkan berbagai lapisan masyarakat dalam jumlah yang tidak sedikit. Bermacam-macam usaha dilakukan agar para korban bencana segera tertangani. Ada yang berusaha menolong dengan cara mengadakan penggalangan dana, mengumpulkan berbagai macam kebutuhan untuk kemudian disalurkan kepada korban, serta terdapat pula individu-individu yang secara langsung terlibat di lapangan untuk bekerja sama membantu proses penanganan dampak negatif pasca bencana alam. Individuindividu tersebut biasanya tergabung dalam komunitas-komunitas maupun kelompokkelompok yang aktif dalam kegiatan penanggulangan bencana alam. Masyarakat umum menyebut individu-individu tadi sebagai relawan. Menurut Badan Nasional Penanggulangan Bencana (BNPB) tentang pedoman relawan penanggulangan bencana, relawan penanggulangan bencana yang selanjutnya disebut relawan adalah seorang atau sekelompok orang yang memiliki kemampuan dan kepedulian untuk bekerja secara sukarela dan ikhlas dalam upaya penanggulangan bencana.

Selain individu-individu yang tergabung dalam kelompok atau komunitas relawan, terdapat pula pihak-pihak lain yang terlibat dalam proses penanganan bencana alam. Pihak-pihak tersebut yakni kepolisian, TNI, maupun aparat-aparat sejenis lainnya. Berdasarkan wawancara yang dilakukan oleh peneliti dengan Manajer Pusat Kendali Operasi Badan Penanggulangan Bencana Daerah Istimewa Yogyakarta (PUSDALOPS BPBD DIY), diketahui bahwa saat terjadi bencana alam tidak hanya relawan yang turun ke lapangan untuk membantu proses penanganannya, tetapi banyak sekali pihakpihak yang terlibat dalam proses tersebut. Bahkan masyarakat umum yang tidak tergabung dalam komunitas atau kelompok relawan mana pun tergerak untuk ikut membantu proses penanganan bencana alam.

Dikarenakan tidak memiliki kemampuan dan kompetensi yang memadai, keterlibatan relawan spontan akan memunculkan masalah lain yang dapat menghambat dan mengganggu proses penanganan bencana alam, seperti masalah 
kesehatan, keamanan, dan keselamatan para relawan spontan itu sendiri (Fernandez, Barbera, \& van Dorp, 2006). Berdasarkan studi yang telah dilakukan oleh Green (2003) terhadap sepuluh orang relawan independen yang tidak tergabung dalam kelompok atau komunitas, ditemukan bahwa walaupun terdapat beberapa di antara mereka yang memiliki pengalaman dalam penanggulangan bencana, banyaknya keterlibatan mereka dalam proses ini tetap dapat menimbulkan berbagai permasalahan yang mampu mengurangi efisiensi proses penanggulangan bencana. Permasalahan tersebut seperti terhambatnya koordinasi antara relawan dan korban, dihadapkannya korban pada risiko-risiko yang tidak semestinya, dan meningkatnya jumlah kematian korban bencana alam (dalam Rogstadius, Karapanos, Teixeira, \& Kostakos, 2013).

Meskipun dinilai kurang mumpuni karena tidak memiliki kemampuan khusus dan pengalaman dalam menangani bencana alam, para relawan spontan ini tetap berusaha untuk menolong para korban. Menolong merupakan perilaku yang pasti akan muncul ketika terjadi situasi darurat layaknya bencana alam. Individu akan menunjukan perilaku lebih peduli dan bertanggung jawab terhadap sesamanya daripada saat situasi berjalan normal atau tidak terjadi bencana alam (Tierney, Lindell, \& Perry, 2001). Rasa peduli dan tanggung jawab ini ditunjukkan dengan banyaknya jumlah relawan spontan yang turun ke lapangan untuk menawarkan bantuan serta pertolongan.

Pandangan negatif para ahli mengenai keterlibatan relawan spontan dalam menolong di lapangan untuk membantu proses penanggulangan bencana alam membuat proses tersebut selalu dinilai belum efektif dan maksimal. Terlebih lagi dengan adanya bukti yang menegaskan bahwa keterlibatan mereka justru akan membahayakan para korban bahkan hingga meningkatkan angka kematian (Rogstadius, Karapanos, Teixeira, \& Kostakos, 2013), meskipun begitu keterlibatan para relawan spontan untuk menolong korban bencana alam tersebut bukan merupakan suatu hal yang sia-sia. Mereka tetap berusaha untuk menolong para korban semampunya, walaupun memang kemampuan khusus yang seharusnya dimiliki oleh relawan belum ada pada diri mereka.

Menolong atau dapat disebut juga helping behavior merupakan sebuah tindakan yang bertujuan untuk menyejahterakan orang lain dengan didorong oleh motif egois maupun altruistic (Bierhoff dalam Marjanovic, Sruthers, \& Greenglass, 2012). Amato (1990) membedakan bentuk perilaku menolong menjadi dua yaitu spontaneous helping dan planned helping. Planned helping sendiri terbagi lagi menjadi dua bentuk yaitu formal planned helping yang merupakan perilaku menolong yang ditujukan untuk membantu seorang individu maupun sekelompok individu melalui sebuah instansi atau organisasi dan informal planned helping yaitu perilaku menolong yang ditujukan kepada individu-individu yang sudah kita kenal dan memiliki kedekatan seperti teman atau anggota keluarga, contohnya adalah meminjamkan uang kepada teman yang membutuhkan, merawat teman atau anggota keluarga yang sedang sakit, serta memberikan makanan kepada teman ataupun tetangga sekitar rumah. Kemudian, spontaneous helping merupakan perilaku menolong yang ditujukan kepada orang-orang asing yang tidak kita kenal. Perilaku ini terjadi secara tiba-tiba atau spontan dan tidak direncanakan sebelumnya. 
Lain halnya dengan Amato, Anne McGuire (1994) mengemukakan empat bentuk perilaku menolong berdasarkan tingkat kepentingan, yang pertama adalah casual helping yaitu merupakan salah satu bentuk perilaku menolong yang berupa bantuan kecil kepada individu yang tidak dikenal. Selanjutnya yang kedua adalah substantial personal helping yakni perilaku menolong yang berupa bantuan dengan skala lebih besar yang diberikan kepada individu yang kita kenal dan memiliki hubungan dengan kita seperti teman dan anggota keluarga. Ketiga adalah emotional helping yaitu salah satu bentuk perilaku menolong dengan memberikan dukungan emosional kepada orang-orang yang kita kenal biasanya orang-orang yang dekat dengan kita. Contoh emotional helping dalam kehidupan sehari-hari adalah mendengarkan curahan hati teman ketika mengalami hal buruk. Terakhir, emergency helping yang merupakan salah satu bentuk perilaku menolong yang cukup sulit karena perilaku ini dilakukan dalam situasi genting dan darurat misalnya menolong orang kecelakaan lalu lintas, atau dalam skala yang lebih besar adalah menolong individu dalam situasi darurat bencana alam. Biasanya, bentuk perilaku menolong emergency helping ini diberikan kepada orang-orang yang tidak dikenal dalam situasi darurat tersebut.

Sama halnya dengan perilaku-perilaku sosial yang lain, perilaku menolong juga dipengaruhi oleh beberapa faktor. Berdasarkan teori-teori yang dikemukakan para peneliti terdahulu, terdapat dua faktor yakni internal dan eksternal. Faktor internal atau faktor disposisional merupakan faktor yang terdapat dalam diri individu penolong sedangkan fakor eksternal atau faktor situasional merupakan faktor yang ada di luar diri individu penolong. Faktor internal terdiri dari empat hal. Pertama, latar belakang individu penolong. Menurut Latane dan Darley (1970), individu yang dibesarkan di kota kecil cenderung lebih suka menolong individu lain dibandingkan dengan individu yang tumbuh di kota besar (dalam Deaux \& Wrightsman, 1984). Menurut Stanley Milgram dalam teorinya yang dikenal dengan nama stimulus overload theory, individu yang tinggal dan tumbuh di kota besar mendapatkan stimulus yang cukup banyak sehingga mereka cenderung lebih selektif dalam merespon berbagai stimulus yang datang. Kecenderungan untuk lebih selektif tersebut kemudian membuat mereka terkadang mengabaikan individu lain yang membutuhkan pertolongan serta selektif pula dalam memilih individu mana yang akan mereka tolong (dalam Deaux \& Wrightsman, 1984). Kedua, norma yang dianut individu penolong. Norma personal merupakan perasaan individu terhadap suatu kewajiban untuk bertindak dengan cara tertentu dan dalam situasi tertentu. Norma personal ini mendorong individu untuk menolong individu lain karena dengan menolong, ia telah memenuhi kewajiban dan bertindak sesuai dengan apa yang diharapkan masyarakat (dalam Deaux \& Wrightsman, 1984). Ketiga, suasana hati. Berdasarkan hasil penelitian eksperimen yang dilakukan Isen dan Levin, dapat disimpulkan bahwa suasana hati yang baik secara konsisten dapat membuat individu memiliki kecenderungan untuk menolong orang lain dalam berbagai situasi. Lebih lanjut ia menjelaskan hal tersebut dapat terjadi karena ketika seorang individu mengalami suasana hati yang baik, maka proses kognitif dan pikirannya akan menjadi positif. Menurut Isen, pikiran dan proses kognitif yang positif berkaitan dengan perilaku menolong dalam diri individu, sehingga ketika individu sedang dalam suasana hati yang baik, ia dengan 
senang hati akan menolong individu lain (dalam Deaux \& Wrightsman, 1984). d). Rasa empati, Menurut hipotesis empatialtruisme yang disampaikan oleh Batson, rasa empati yang ada dalam diri individu merupakan kunci munculnya perilaku menolong. Empati sendiri diartikan sebagai kemampuan seorang individu untuk memahami apa yang dirasakan individu lain dan meresponnya secara emosional (dalam Kassin, Fein, \& Markus, 2011).

Selain faktor internal, ada pula faktor eksternal yang memengaruhi munculnya perilaku menolong. Pertama, karakteristik individu yang membutuhkan pertolongan. Karakteristik yang paling berpengaruh adalah sifat ketergantungan yang ada pada diri individu (Deaux \& Wrightsman, 1984). Selain karena sifat ketergantungan yang ada pada diri individu, kesamaan yang dimiliki antara individu penolong dengan individu yang membutuhkan pertolongan merupakan salah satu faktor penting yang memengaruhi perilaku menolong (Deaux \& Wrightsman, 1984). Persepsi kesamaan tersebut meningkatkan kecenderungan individu penolong untuk memberikan pertolongan kepada individu yang memiliki kesamaan dengannya (Lichtenbarger, 1999).

Kedua, norma sosial yang berlaku di masyarakat. Salah satu norma sosial yang berkaitan dengan perilaku menolong adalah social responsibility norm. Norma tersebut mengatakan bahwa kita memiliki kewajiban untuk menolong individu-individu yang membutuhkan pertolongan (Berkowitz \& Daniels, dalam Deaux \& Wrightsman, 1984). Kemudian, selain social responsibility norm terdapat norma lain yang lebih kuat dan mengikat yakni reciprocity norm. Gouldner mengatakan bahwa individu memiliki kewajiban untuk menolong individu lain yang sebelumnya pernah menolong dirinya (dalam Deaux \& Wrightsman, 1984).
Ketiga, keberadaan orang lain. Keberadaan orang lain juga merupakan faktor yang dapat memengaruhi perilaku menolong. Individu cenderung tidak akan menolong orang yang membutuhkan pertolongan ketika banyak individu-individu lain di sekitarnya. Fenomena tersebut dikenal dengan nama bystander effect (Deaux \& Wrightsman, 1984).

\section{Metode}

Pendekatan yang digunakan dalam penelitian ini adalah pendekatan kualitatif fenomenologi. Metode pengambilan data menggunakan wawancara semi terstruktur yakni dengan menggunakan panduan wawancara yang telah dibuat sebelum sesi wawancara berlangsung.

Partisipan dalam penelitian ini memiliki kriteria seperti berikut: 1) Laki-laki atau perempuan berusia 20-55 tahun, 2) Berdomisili di Daerah Istimewa Yogyakarta dan sekitarnya, 3) Bersedia menjadi informan penelitian, 4) Pernah membantu proses penanganan bencana alam seperti banjir, longsor, gempa bumi, erupsi gunung, dll. secara independen. Penelitian ini melibatkan tiga orang informan. Data penelitian yang didapat dianalisis menggunakan Interpretative Phenomenological Analysis (IPA) dan diuji keabsahannya menggunakan triangulasi sumber dengan mewawancara significant other para informan.

\section{Hasil}

Berdasarkan wawancara yang telah dilakukan kepada tiga informan utama dan tiga significant other, ditemukan bahwa terdapat perubahan bentuk perilaku menolong dari perilaku menolong yang spontan atau disebut spontaneous helping menjadi perilaku menolong terencana atau planned helping pada ketiga informan yang 
menjadi relawan spontan. Selain itu, perilaku menolong spontan muncul ketika terjadi suatu kondisi darurat dalam hal ini adalah bencana alam. Perilaku spontan tersebut didorong oleh perasaan empati yang sangat mendalam ketika melihat kondisi dengan membayangkan apa yang dialami korban kepada diri informan. Terakhir, perilaku tersebut didorong oleh rasa ingin tahu yang tinggi terhadap kondisi bencana alam. Selain ketiga faktor tersebut, ditemukan juga satu faktor eksternal yang mendorong perilaku menolong spontan ketiga informan yaitu adanya dorongan dari orang tua mereka masing-masing serta faktor lingkungan tempat tinggal yang membentuk perilaku menolong.

Para relawan spontan memiliki nilainilai kepekaan sosial yang terinternalisasi dalam diri mereka. Internalisasi kepekaan ini ditunjukkan dengan aktivitas mereka yang konsisten. Beberapa tahun setelah menjadi relawan spontan saat bencana erupsi Merapi dan longsor Banjarnegara, ketiga informan melanjutkan kontribusi mereka untuk menolong dengan bergabung ke dalam organisasi relawan bencana. SG bergabung ke PMI Magelang dan Tanggap Darurat, $\mathrm{AD}$ bergabung ke Disaster Response Unit, sedangkan NR bergabung ke Muhammadiyah Disaster Management Center. Berdasarkan wawancara yang telah dilakukan kepada ketiga informan, ditemukan faktor pendorong lain yang diasumsikan mendorong mereka untuk bergabung ke organisasi relawan yaitu sifat penolong yang ada dalam diri masingmasing individu, modeling perilaku menolong yang dilakukan anggota keluarga informan serta pengaruh lingkungan tempat tinggal informan.

\section{Diskusi}

Perilaku menolong yang muncul pada ketiga informan dan telah dijelaskan di atas merupakan perilaku menolong spontan yang berlatar situasi darurat bencana alam. Berdasarkan temuan di lapangan, dorongan yang memunculkan perilaku menolong spontan pada diri mereka berasal dari kondisi yang dilihat maupun didengar oleh para informan yang kemudian menimbulkan perasaan empati serta rasa ingin tahu akan keadaan lokasi bencana alam. Menurut Clary dan Orenstein (1991), faktor situasional atau yang biasa disebut faktor eksternal lebih memiliki andil dalam mendorong munculnya perilaku menolong spontan dibandingkan dengan faktor disposisional atau faktor internal yang datang dari dalam diri individu. Namun, dalam penelitian ini ditemukan bahwa faktor situasional dan faktor disposisional memiliki peran dalam mendorong munculnya perilaku menolong spontan. Faktor situasional dalam hal ini kondisi lokasi bencana dan para korban memunculkan rasa empati dari para informan yang kemudian mendorong perilaku menolong. Kedua faktor tersebut saling berinteraksi dalam memunculkan perilaku menolong spontan. Hal tersebut selaras dengan apa yang dikatakan oleh Magnusson \& Endler (dalam Staub, 2003) bahwa suatu perilaku akan muncul karena adanya interaksi dan saling keterkaitan antara faktor situasional dengan faktor disposisional.

Penelitian yang dilakukan oleh Toi dan Batson (1982) menunjukan bahwa munculnya rasa empati dalam diri individu ketika dihadapkan pada situasi yang membutuhkan pertolongan akan mendorong kemunculan perilaku menolong. Sejalan dengan penelitian tersebut, Coke et al., (1978) menyajikan dua komponen kunci dalam pembentukan perilaku menolong. 
Menurutnya ketika individu melihat dirinya dari sudut pandang para korban yang membutuhkan pertolongan, hal tersebut akan meningkatkan respon emosional yang kemudian akan memunculkan rasa empati. Selanjutnya, rasa empati tersebut akan mendorong individu untuk menolong individu lain yang membutuhkan pertolongan. Hal tersebut tampak pada temuan penelitian yang muncul pada informan SG. Ketika dihadapkan pada kondisi sulit maupun darurat, SG kemudian memandangnya dari sudut pandang individu yang membutuhkan pertolongan. Ia memikirkan bagaimana jika dirinya, keluarganya maupun orang-orang terdekatnya mengalami hal seperti itu. Dari hal itulah kemudian rasa empati dalam diri SG muncul hingga akhirnya mendorong dirinya untuk menolong orang lain. Selain rasa empati, rasa ingin tahu yang ada dalam diri individu juga dapat mendorong munculnya perilaku menolong. Menurut Clary dan Snyder (1999), salah satu faktor yang mendorong seorang relawan untuk menolong adalah knowledge function, yaitu ketika ia berusaha untuk mempelajari suatu kondisi maupun suatu keterampilan khusus.

Di samping faktor pendorong yang telah dijabarkan di atas, ditemukan pula satu faktor lain yang berasal dari luar diri individu penolong yang dapat mendorong munculnya perilaku menolong spontan para informan. Faktor tersebut merupakan dukungan yang datang dari orang tua masing-masing informan. Menurut Tec, dukungan dari keluarga dan orang-orang terdekat merupakan salah satu faktor yang penting untuk mendorong munculnya perilaku menolong (dalam Bordens dan Horowitz, 2008). Selanjutnya, pada ketiga informan ditemukan faktor pendorong lain yang diasumsikan lebih berperan dalam mendorong berlanjutnya perilaku menolong mereka menjadi perilaku menolong terencana. Faktor tersebut adalah sifat yang dimiliki ketiga informan, modeling terhadap perilaku menolong yang dilakukan oleh anggota keluarga informan, serta harapan akan pekerjaan di masa depan.

Penelitian eksperimen yang dilakukan Staub (2003) menunjukan bahwa individu dengan kepribadian yang dinilai lebih prososial akan cenderung lebih mudah terdorong untuk menolong orang lain. Hal tersebut dibuktikan dengan skor tinggi yang didapatkan individu dari tes yang berkaitan dengan perilaku menolong. Dalam penelitian ini, ketiga informan dinilai memiliki sifat kepedulian yang cukup besar kepada orang lain maupun lingkungan di sekitar mereka berdasarkan pengamatan orangorang terdekat yang terjun ke lokasi bencana alam bersama informan dan telah diwawancarai. Menurut significant others masing-masing, ketiga informan merupakan pribadi yang sangat peduli dengan orangorang di sekitarnya. Mereka tidak segan untuk menolong orang lain yang sedang mengalami kesulitan. Selain sifat yang ada pada diri ketiga informan, ditemukan juga bahwa dengan mencontoh perilaku menolong yang dilakukan anggota keluarga dapat mendorong terbentuknya perilaku yang sama. Grusec (dalam Dovidio dan Penner, 2001) mengatakan bahwa dengan mengamati perilaku menolong orang tua maupun orang-orang terdekat, perilaku menolong seorang anak dapat terdorong untuk muncul. Baik perilaku menolong spontan maupun perilaku menolong jangka panjang keduanya dapat didorong oleh modeling yang dilakukan individu. Kemudian Fabes, Eisenberg, dan Miller (dalam Dovidio dan Penner, 2001) menemukan bahwa seorang anak perempuan yang berempati kepada teman-teman 
di sekolahnya yang sedang dalam kesulitan, memiliki seorang ibu yang juga berempati kepada orang lain dalam situasi yang sama. Ini menunjukan bahwa perilaku anak perempuan tersebut adalah hasil dari modeling perilaku sang ibu.

Kemudian, dalam penelitian ini juga ditemukan bahwa harapan seorang individu akan pekerjaannya yang diinginkan di masa depan dapat mendorong munculnya perilaku menolong. Clary dan Snyder (1999) menyebutkan bahwa salah satu faktor yang mendorong individu untuk bergabung dalam kegiatan kerelawanan jangka panjang adalah career function. Career function merupakan faktor dimana seorang individu ikut serta dalam kegiatan kerelawanan karena dirinya memiliki harapan dan tujuan untuk pekerjaan yang berkaitan dengan pengalamannya saat menjadi seorang relawan. Selain ketiga faktor internal, yakni sifat dalam diri individu penolong, proses modeling, dan career function, ditemukan pula satu faktor eksternal yang dapat memunculkan perilaku menolong terencana yakni lingkungan tempat tinggal individu yang berkaitan dengan adanya budaya tolong menolong. Menurut penelitian yang dilakukan oleh Lucian Conway, dkk. (dalam Kassin, Fein, \& Markus, 2011), individu merasa mengemban tanggung jawab yang jauh lebih sedikit dan akhirnya cenderung tidak akan memunculkan perilaku menolong. Lalu berdasarkan penelitian yang dilakukan oleh Fritzsche, Finkelstein, dan Penner (2000), ditemukan bahwa beban yang akan ditanggung oleh penolong merupakan salah satu faktor yang dapat menghambat munculnya perilaku menolong. Menurut mereka, ketika beban yang akan ditanggung oleh penolong cukup berat, maka kemungkinan munculnya perilaku menolong akan semakin kecil. Selain itu, salah satu hal yang dapat menjadi beban yang tinggal dalam lingkungan yang menyukai kebersamaan dan kolektivis atau berfokus pada kelompok, akan lebih mudah untuk memunculkan perilaku menolong mereka dibandingkan dengan individu yang tinggal dalam lingkungan individualistis atau berfokus pada diri masingmasing.

Di samping faktor-faktor pendorong yang telah dipaparkan di atas, ditemukan pula faktor penghambat yang tidak memunculkan perilaku menolong pada informan. Salah satu faktor penghambat tersebut adalah keberadaan orang lain di lokasi bencana alam. Menurut Deaux dan Wrightsman (1984), individu cenderung tidak akan menolong individu lain yang membutuhkan pertolongan ketika sudah banyak orang-orang yang berpotensi untuk menjadi penolong di sekitar mereka. Kemudian, banyaknya individu yang hadir di lokasi kejadian pun akan menimbulkan suatu fenomena yang disebut sebagai difussion of responsibility. Diffusion of responsibility merupakan kondisi dimana jumlah individu yang berpotensi untuk menolong cukup banyak, maka dapat dikatakan tanggung jawab untuk menolong akan terbagi dan tersebar pada setiap

adalah waktu yang dibutuhkan untuk memberikan pertolongan. Ketika waktu yang dibutuhkan untuk menolong cukup banyak, maka individu cenderung tidak akan memunculkan perilaku menolong.

Selanjutnya, Baron dan Branscombe (2012) dalam bukunya mengatakan bahwa waktu yang digunakan individu untuk menolong orang lain tidak dapat digunakan untuk melakukan kegiatan lain seperti halnya kegiatan yang berkaitan dengan nilai-nilai ekonomi yakni bekerja dan menghasilkan uang. Apabila individu memikirkan kepentingan ekonomi ketika 
akan menolong orang lain, maka hal tersebut akan membuatnya cenderung untuk tidak memunculkan perilaku menolong. Hal ini mengacu pada penelitian yang dilakukan oleh DeVoe dan Pfeffer (2010) yang menunjukan bahwa ketika seorang individu memasukan nilai-nilai ekonomi dalam waktu yang akan digunakan untuk menolong, mereka cenderung tidak akan melakukannya dan kemudian memilih untuk melakukan pekerjaan.

\section{Penutup}

Berdasarkan hasil temuan penelitian yang telah dijabarkan dan dibahas pada bagian sebelumnya dapat disimpulkan bahwa perilaku menolong adalah perilaku yang dapat muncul secara spontan ketika melihat individu lain dalam kesulitan dan bertujuan untuk meringankan beban individu tersebut, sehingga nantinya perilaku menolong yang telah dilakukan akan mendatangkan kebaikan bagi yang melakukannya. Selanjutnya, perilaku menolong dapat dilakukan secara langsung maupun tidak langsung. Menolong secara langsung dapat dilakukan dengan berinteraksi langsung dengan orang yang membutuhkan bantuan, sedangkan menolong secara tidak langsung dapat dilakukan dengan melakukan kegiatan lain seperti penggalangan dana, donasi, dan lain-lain. Kemudian, relawan bencana alam adalah individu yang memiliki keikhlasan lahir dan batin sehingga ia berdedikasi tinggi dalam menolong korban bencana alam. Dedikasi tinggi tersebut ditunjukkan dengan kesiapan dan kesigapannya untuk menolong korban bencana.

\section{Saran}

Berikut adalah beberapa saran yang dapat diberikan untuk pihak-pihak yang membutuhkan serta untuk perkembangan penelitian selanjutnya. Masyarakat umum yang ingin membantu dalam penanganan bencana alam sebaiknya bekal ilmu pengetahuan dan kemampuan yang cukup untuk menolong korban agar aparat dan relawan yang berasal dari organisasi tidak merasa direpotkan dengan kehadiran mereka.

Bagi peneliti selanjutnya yang tertarik dengan tema relawan dan perilaku menolong, ada baiknya apabila menggunakan informan dengan rentang usia yang lebih bervariasi, misal informan A berusia 23 tahun, informan B berusia 35 tahun, dan informan $C$ berusia 50 tahun. Selain rentang usia, faktor jenis kelamin juga sepertinya menarik untuk dibahas lebih lanjut, apakah individu dengan jenis kelamin laki-laki cenderung lebih suka menolong dibandingkan dengan yang berjenis kelamin perempuan atau sebaliknya. Selain itu, faktor kultural juga dapat lebih digali lagi karena lokasi penelitian berada di kota yang sarat akan budaya yakni Yogyakarta, sehingga akan banyak sekali data menarik yang bisa didapatkan apabila lebih melihat kepada faktor budaya yang memengaruhi perilaku menolong individu. Kemudian peneliti selanjutnya juga dapat menggali dari sisi individu yang membutuhkan pertolongan mengenai bagaimana perilaku mereka dalam mencari pertolongan atau yang disebut dengan help-seeking behavior.

\section{Kepustakaan}

Amato, P. R. (1990). Personality and social network involvement as predictors of helping behavior in everyday life. Social Psychology Quarterly, 53, 31-43.

Baron, R. A., \& Branscombe, N. R. (2012). Social psychology thirteenth edition. New Jersey: Pearson.

Bordens, K. S., \& Horowitz, I. A. (2008). Social psychology third edition. Minnesota: Freeload Press. 
CFE-DMHA. (2015). Indonesia disaster management reference handbook. Hawaii: Center for Exellence in Disaster Management and Humanitarian Assistance.

Clary, E. G., \& Snyder, M. (1999). The motivations to volunteer: Theoretical and practical considerations. Current Directions in Psychological Science, 8(5), 156-159.

Coke, J. S., Batson, C. D., \& McDavis, K. (1978). Empathic mediation of helping. Journal of Personality and Social Psychology, 36, 752-766.

Deaux, K., \& Wrightsman, L. S. (1984). Social psychology in the 80s. California: Brooks/Cole Publishing Company.

DEPDIKBUD. (1982). Sistim gotong royong dalam masyarakat pedesaan Daerah Istimewa Yogyakarta. Jakarta: Proyek Inventarisasi dan Dokumentasi Kebudayaan Daerah.

DeVoe, S. E., \& Pfeffer, J. (2010). The stingy hour: How the practice of billing time affects volunteering. Personality and Social Psychology Bulletin, 36, 470-483. doi:10.1177/0146167209359699

Dovidio, J. F., \& Penner, L. A. (2001). Helping and Altruism. In G. J. Flecher, \& M. S. Clark, Blackwell handbook of social psychology: Interpersonal processes (pp. 162-195). Padstow: Blackwell Publishing.

Fernandez, L. S., Barbera, J. A., \& van Dorp, J. R. (2006). Spontaneous volunteer response to disaster: The benefits and consequences of good intentions. Journal of Emergency Management, 4(5), 57-68.

Fritzsche, B. A., Finkelstein, M. A., \& Penner, L. A. (2000). To help or not to help: Capturing individuals' decision policies. Social Behavior and Personality, 28, 561-578.
Israel, B. (2010, October 26). Indonesia's Explosive Geology Explained. Retrieved from Live Science: http://www.livescience.com/8823indonesia-explosive-geologyexplained.html

Kassin, S., Fein, S., \& Markus, H. R. (2011). Social psychology 8E. California: Wadsworth Cengage Learning.

Latane, B., Darley, J.M. (1970). The Unresponsive Bystander: Why Doesn't He Help?. New York, NY: Appleton Century Crofts.

Lichtenbarger, D. M. (1999). The effects on similarity on altruism and its relationship to predicted versus actual helping behavior. Indiana University Undergraduate Research Conference (pp. 46-50). Indiana: SMART grant.

Malau, I. L., \& Waskita, D. (2012, May 25). BNPB Antisipasi potensi siklus 4 tahunan Merapi. Retrieved from Viva.co.id: http://nasional.news.viva.co.id/news/r ead/420772-bnpb-antisipasi-potensisiklus-4-tahunan-erupsi-merapi

Marjanovic, Z., Sruthers, C. W., \& Greenglass, E. R. (2012). Who helps natural-disaster victims? Assessment of trait and situational predictors. Analyses of Social Issues and Public Policy, 12(1), 245-267.

Martono, J. (2013, May 27). Mengenang gempa tektonik 2006 di Yogyakarta dan sekitarnya (1). Retrieved from Kompasiana:

http://www.kompasiana.com/jk.marto no/mengenang-gempa-tektonik-2006di-yogyakarta-dan-sekitarnya1_5520a164a33311764646d137

McGuire, A. M. (1994). Helping behaviors in natural environment: Dimensions and correlates of helping. Personality and Social Psychology Bulletin, 20, 45-56. 
Rogstadius, J., Karapanos, E., Teixeira, C., \& Kostakos, V. (2013). An introduction for system developers to volunteer roles in crisis response and recovery.

10th International ISCRAM Conference, (pp. 874-883). Baden-Baden.

Staub, E. (2003). The psychology of good and evil : Why children, adults, and groups help and harm others. New York: Cambridge University Press.

Toi, M., \& Batson, C. D. (19820. More evidence that empathy is a source of altruistic motivation. Journal of Personality and Social Psychology, 42, 281-292.

Veriawan, O. (2014). 68 persen wilayah DIY rawan bencana. Retrieved from Tribun Jogja:

http://jogja.tribunnews.com/2014/09/23 /68-persen-wilayah-diy-rawanbencana 